\title{
V. 合併症を併発した大腸憩室疾患の診断と治療一出血一
}

\author{
福田 眞作 三上 達也 \\ 弘前大学大学院医学研究科消化器血液内科学講座
}

\begin{abstract}
大腸悡室からの出血の診断と治療には，下部消化管内視鏡が非常に有用である.
\end{abstract}
咊室からの新鮮血の流出あるいは憩室内に露出血管が確認できれば出血源と診断できる. しかし, 大腸 息室は多発していることが多く, 実際にはどの喤室から出血しているのかわからないことが多い. 自然に 止血されることが多い疾患ではあるが, 抗血小板薬あるいは抗凝固薬を内服中の場合には自然止血後も再 出血する危険があるため注意が必要である.

大腸䟤室は筋層を欠く仮性䟤室であるため, 熱凝固法やエタノール局注などによる止血は, 穿孔の危険 があり控えるべきである．組織障害の少ないクリップによる止血がもっとも有用である.

内視鏡による診断あるいは治療が困難であり, 出血が持続する場合には, 夕イミングを逃さずに血管造 影または外科的手術を考慮する必要がある。

索引用語 : 大腸箇室, 合併症, 出血

はじめに

大腸㮩室疾患の合併症のひとつである㮩室出血 は，腹痛・発熱などの㮩室炎にともなう症状を呈す ることは少なく，無症状かつ突然の血便で発症する ことが多い. 近年, 人口の高齢化, 食生活の欧米化 にともない大腸憩室疾患は増加している，高齢者に 多いことから，脳血管疾患や虚血性心疾患に対する 治療薬（抗血小板薬や抗凝固薬）を内服しているこ とも多く，一旦止血が得られたと思われた後に再出 血をきたすことも稀ではない. 憩室出血は, 安静,

絶食, 輸血・補液などの保存的治療によって多くは 自然止血するが, 未治療例では高率に再出血がみら れることが知られている1). したがって, 積極的に出 血㮩室を診断し，治療を行うべきである.

憩室出血の診断と治療の基本は内視鏡によるもの であるが, 内視鏡による診断・止血が困難な場合に は血管造影を用いた止血（interventional radiology；IVR）あるいは外科的治療を考慮する.

本項では, 大腸憩室出血の診断と治療法について 述べ, 最後に内視鏡的に止血し得た症例を呈示する.

\section{I. 覣室出血に対する大腸内視鏡}

内視鏡検査は, 他の血便をきたす疾患と本疾患と の鑑別のみならず，治療（内視鏡的止血）に直結す る極めて有用な検査法である.

\section{1. 内視鏡を挿入する前に}

内視鏡を挿入する前に, 全身状態を把握すること を忘れてはならない. バイタルサイン・末梢血など をチェックし，低血圧，貧血，頻脈を有するなど循 環動態が不安定な場合には, 適宜輸血や輸液を行い 全身状態の改善に努める.

また，問診や診察から，血便をきたす疾患との鑑 別をある程度行い, 腹膜刺激症状などの内視鏡挿入 が禁忌の状態にないことを確認する.

\section{2. 前処置}

血便症例に対する前処置として, (1)通常の前処置 (腸管洗浄液), (2)高圧浣腸による洗腸, (3)グリセリ ン浣腸, (4)無処置, の4つが考えられる. 以前は無 処置で緊急内視鏡を行うことが推奨されてきたが, 大量の糞便・凝血塊の存在によって深部挿入や観察 が困難なことが多い。バイタルサインが安定してい る場合には，腸管洗浄液による前処置が望ましく， 出血憩室同定率の向上につながる。ただし, 潰瘍性 
大腸炎や腸閉塞に近い状態の進行大腸癌など，腸管 洗浄液で状態が悪化する疾患がないことを確認する 必要がある．頻回に鮮出血がみられる場合には，腸 管内に糞便の残存はほとんど無く, 前処置なしか, グリセリン浣腸あるいは高圧浣腸のみでも十分に観 察可能である．ただし，浣腸によって本来の出血部 位よりも口側に血液が逆流することを認識しておく 必要がある。

\section{3. 内視鏡による出血源の同定と治療}

残渣, 凝血塊の存在によって視野が不良であるこ と，また憩室多発症例では深部挿入に難渋すること が少なくないことなどから，悪条件下での緊急内視 鏡を数多く経験した術者が施行することが望まし い，出血源の同定や止血処置には，長時間を要する ことも稀でない，また，視野を確保するために，十 分な送気を必要とする場合が多く，術中に強度の腹 部膨満によって，血圧の低下や徐脈を呈することが ある，腹部膨満感の軽減，過度の腸管伸展による迷 走神経反射を防止するために，内視鏡の送気に，通 常の空気ではなく, 吸収の極めて早い炭酸ガスを用 いる方法がある ${ }^{2}$. 患者の苦痛軽減, 偶発症のリスク を低下させる効果が期待できる.

最初に直腸を慎重に観察し, 痔からの出血や高齢 者に多い出血性直腸潰瘍をまず鑑別する。これらの 病変は, 直腸粘膜への糞便の付着によって隠され, 挿入時に見逃されることがある．直腸を十分に洗浄 観察後，可能な限り深部までスコープを挿入する. 盲腸まで到達し得たら，小腸出血を鑑別するために 終末回腸へスコープを挿入し，回腸液の性状を観察 する.ただし，終末回腸に凝血塊があったとしても， 盲腸・上行結腸からの逆流の可能性を念頭におき, 慎重に判断する．出血部位の予測に，大腸内の凝血 塊の存在範囲が参考になることもあるが，前処置の 影響や出血からの夕イムラグなどを考慮して判断す る必要がある。

血便症例では，大腸粘膜に残渣と凝血塊が付着し ておりこれらを入念に洗浄しながら，出血をきた すような腫瘍性病変，血管性病変（angioectasia な ど)，大腸喤室などの同定に全力を注ぐ．とくに，悡 室内には出血㮩室でなくても凝血塊が入り込んでい ることが多く，根気よく凝血塊を洗い流して観察す る必要がある。

憩室からの新鮮血の流出が確認できれば出血源と
診断できるが，大腸憩室からの出血は自然に止血が 得られることが多いことは冒頭に述べた通りであ る.したがって, 咊室の存在を確認できても, 唕室 からの出血なのか, どの憩室からの出血なのか, 的 確に診断できないことが少なくない（出血賃室の同 定率 $33 \%)^{3)}$. 近年, 喤室出血の診断に先端透明フー ドが有用であることが報告されている ${ }^{4)}$ 透明フード の装着によって，赤玉になりにくく，ヒダを押さえ 込んでのヒダ奥の観察など，観察困難な部位も容易 に視認できる。また，止血状態にある多発する咊室 から出血㮩室を同定するには，先端フードを㮩室に 押し付け，軽く吸引することによって悡室を反転さ せ，咊室内を観察する方法が有用である．喤室から の再出血, 䄭室内の凝血塊付着, びらん, 露出血管 が確認できれば出血頽室と診断できる.

出血憩室が明確に同定できれば，内視鏡的に止血 が可能なことが多い．大腸悡室は筋層を欠く仮性熄 室であるため, 悡室壁は非常に薄い. ヒータープロー ブあるいは APC (argon plasma coagulation) などに よる熱凝固による止血法や組織障害の強いエタノー ル局注法は，穿孔の危険性があり，避けるべきであ る.したがって, 組織障害の少ない機械的止血法で あるクリップ止血法 ${ }^{5.6)}$ やバンド結紮法 ${ }^{7.8}$ が推奨され るが，本邦ではクリップ止血法が選択されることが 多い．憩室底の露出血管を狙ってのクリッピングは 穿孔の危険性があるので，複数のクリップで媳室開 口部を塞ぐようにする ${ }^{9)}$ ほとんどの場合クリップ単 独で止血が得られるが，それでも出血が続く場合に は，組織障害が比較的少ない高張 $\mathrm{Na}$-エピネフリン 液を憩室の周囲数力所に局注する方法もある ${ }^{10,11)}$.

内視鏡的に止血が得られたら，可能な限り大腸内 の凝血塊を洗浄・吸引してから検査を終了する。こ れにより，止血後に血便がみられた場合に再出血の 可能性が高いと即座に判断できる。

\section{4. 内視鏡的止血後の管理}

排出便の性状，採血などの結果から完全な止血が 得られたと確認できるまでは絶飲食とし，輸液によ る管理を行う。

内服していることの多い抗血小板薬・抗凝固薬に ついては，原疾患リスクについて関連診療科と十分 に協議した上で，休薬の可否を決定する．休薬する 際には休薬にともなうリスク（虚血性心疾患などの 原疾患悪化の可能性）を，逆に休薬が不可能な場合 


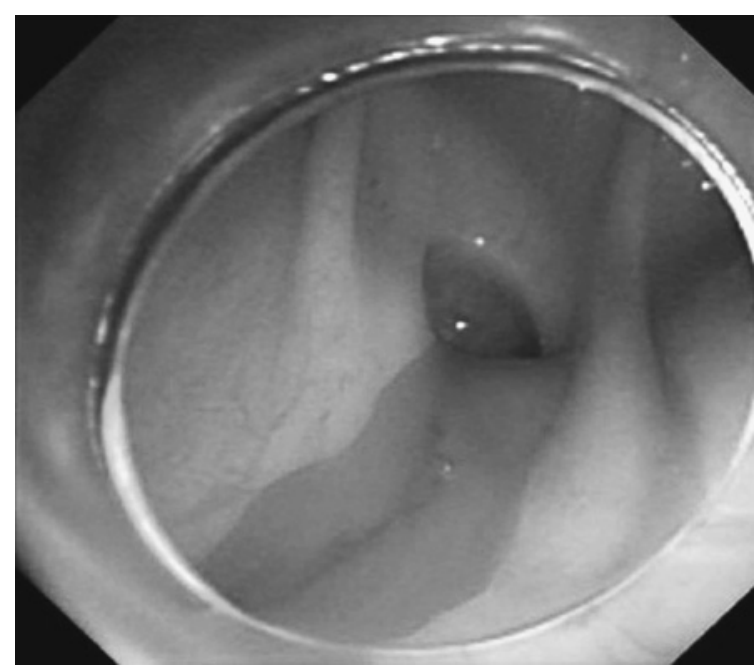

図 1 多発する㮩室の一つから新鮮血の流出を認めた.

には再出血のリスクを説明し，同意を得ておく．

\section{II. その他の止血法}

\section{IVR (interventional radiology)}

内視鏡的止血が困難であった場合，あるいは輸 液・輸血を行った後でも血圧が保てず，全身状態が 不良なために内視鏡の挿入自体が困難な場合には, 内視鏡的止血に固執することなく血管造影を用いた 止血 (IVR) あるいは外科的治療を選択する必要があ る. 血管造影では, $0.5 \mathrm{ml} / \mathrm{min}$ 以上の出血がある場合 に部位の同定が可能であるが, 一時的な止血状態で は血管外漏出を認めず，診断は困難である。いつ検 查を施行するのか，その夕イミングが重要である. 出血血管が確認できたら，超選択的血管塞栓術によ る止血を試みる。止血に成功しても，腸管壊死，穿 孔性腹膜炎などの合併症を発症することがある。腹 部所見に注意し, 腹部 X 線検查や腹部 $\mathrm{CT}$ 検査, 血 液検査を適宜行うとともに, 抗生物質を予防投与する.

\section{2. 外科的治療}

内視鏡的治療や IVR などの保存的治療で止血困 難な場合や，短期間に出血を繰り返す場合には，結 腸切除の適応である．出血部位が不明の場合に選択 される結腸覀全摘術の予後は不良である ${ }^{1)}$. 予後が良 好な結腸部分切除に止めるためにも, 内視鏡検查, 腹部造影 CT, 血管造影, 出血シンチグラフィーなど を駆使し，出血部位の同定に努めるべきである．出 血シンチグラフィーは, 血管造影よりも緩徐な出血 (0.05 0.5ml $/ \mathrm{min}$ 以上) や間欠的な出血であっても
部位診断が可能とされている

\section{3. バリウム充填法}

腹部 X 線写真でよくみかけるように, バリウムは 長期間にわたって鄎室内に残存する。古典的な䅣室 出血の治療法として, バリウム充填法がある ${ }^{13)}$. 最近 では，高濃度のバリウムが有効との報告もみられ ${ }^{14}$, 少量の出血を繰り返し, 種々の検査で診断が困難な 症例に対する治療法として興味深い.

\section{III. 症例呈示}

症例は 70 代の男性. 虚血性心疾患に対し, 他医か らの抗血小板薬を内服中であった。深夜に突然無痛 性の血便あり, 翌日未明に近医受診し緊急入院と なった. $\mathrm{Hb} 12.4 \mathrm{~g} / \mathrm{d} l$ であり, バイタルサインは落ち 着いていた.

同日朝，一時的な血圧の低下がみられたが，輸液 のみで血圧が安定したため, 緊急大腸内視鏡を施行 した，凝血塊多量のため S 状結腸までしか挿入でき ず，出血源は不明であった，夕方に再び血圧の低下 があり, $\mathrm{Hb} 9.2 \mathrm{~g} / \mathrm{d} l$ と低下しており, 輸血 (RCC 800 $\mathrm{ml}$ ) が行われた。

翌朝に三度目の血圧の低下あり，輸血後に血管造 影が施行されたが, 出血源不明であった. 同日夕方, 当科紹介・緊急入院となった. 起床後からまったく 血便がみられていないこと, 血管造影にて出血源が 不明で, 輸血後の $\mathrm{Hb}$ が $11.0 \mathrm{~g} / \mathrm{d} l$ まで改善している ことから, 止血状態にあると判断した. ところが, その夕方に狭心症様の症状とともにショック状態と なり, 貧血の進行を認めた $(\mathrm{Hb} 7.5 \mathrm{~g} / \mathrm{d} l)$. 輸血後, 前処置なしで緊急大腸内視鏡を開始した.

フードを装着して挿入を開始した，直腸から凝血 塊を多量に認め, 挿入に難渋したが回腸末端まで挿 入することができた。回盲弁近傍の数室から新鮮血 の流出がみられ (図 1), 水洗して喤室内を観察する と露出血管が確認できた (図 2). 熄室の開口部を閉 じるようにクリッピングを行うことによって止血さ れた（図 3).

その後血便や $\mathrm{Hb}$ の低下もなく，6日後に摂食を 再開, 悪化のないことを確認して退院となった.

本症例のように抗血小板薬を内服中に憩室出血を きたした際には，一時止血を得られたと思われても 再出血をきたし, ショックとなることがある. また, 血管造影を施行しても，タイミングによっては出血 


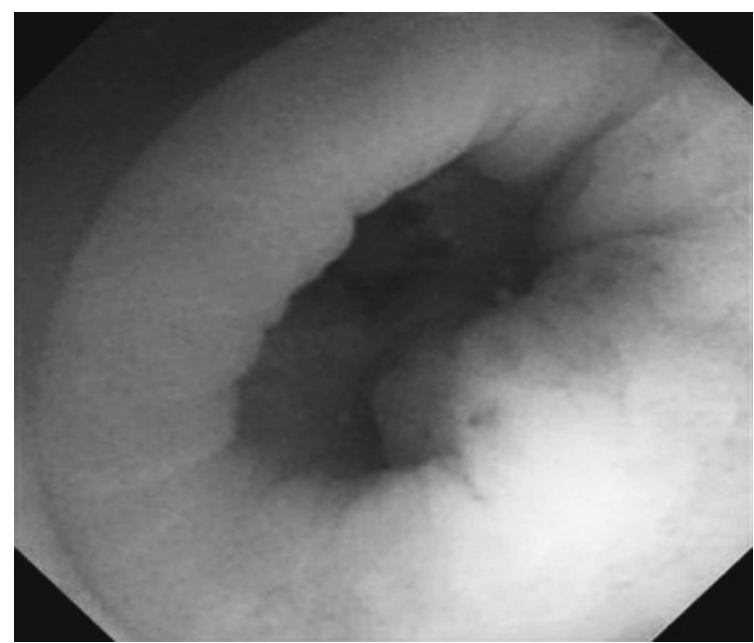

図 2 フードを押し付けて水洗すると悡室内に露出血管を認 めた。

源の同定が困難な典型例である．全身状態によって は緊急手術も考慮せざるを得ない症例であるが，内 視鏡を施行できる状態であれば，可能な限り出血源 を捉え，処置することが望ましい，仮に，止血がで きなくても, その後の外科的治療の際の切除範囲の 重要な情報源となる.

\section{おわりに}

高齢化社会を反映し，今後遭遇する機会が増える であろう咊室出血の診断と治療法を述べた．幸いな ことに，デバイスの進歩や様々な工夫によって，内 視鏡下での出血源の同定率は向上し，同時に内視鏡 的止血が可能な症例が増えてきている．時期を逃さ ず，適切な前処置のもとで，入念に洗浄と吸引を繰 り返し詳細に観察することの重要性を再度強調し, 項を終える。

\section{参考文献}

1) McGuire HH: Bleeding colonic diverticula. A reappraisal of natural history and management. Ann Surg 220: 653656,1994

2）斎藤 豊, 菊池 剛, 福澤誠克ほか：大腸 ESD に対する 工夫と進歩。胃と腸 $42: 1101-1107,2007$

3）小林清典, 横山 薰, 佐田美和ほか: 出血性病変に対す る止血術．臨床消化器内科 $20: 1795-1802,2005$

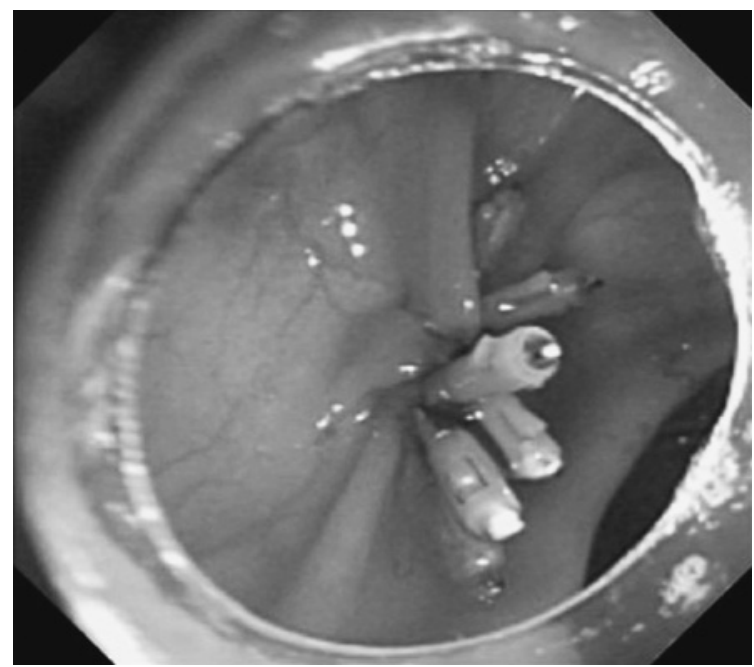

図 3 クリップ 6 個で㮩室の開口部を塞ぎ, 止血が得られた。

4）杉山 宏, 土屋朝則, 金森 堂ほか：透明フードを用い た大腸秝室出血の内視鏡診断. 臨林消化器内科 18 ： 731-735, 2003

5) Hokama A, Uehara T, Nakayoshi $T$, et al: Utility of endoscopic hemoclipping for colonic diverticular bleeding. Am J Gastroenterol 92: 543-544, 1997

6）須藤一郎, 石塚大輔，丸田和夫ほか：大腸悡室出血と内 視鏡治療. 消化器内視鏡 $11: 1289-1293,1999$

7) Witte JT: Band ligation for colonic bleeding: modification of multiband ligating devices for use with a colonoscope. Gastrointest Endosc 52: 762-765, 2000

8) Farrell JJ, Graeme-Cook F, Kelsey PB: Treatment of bleeding colonic diverticula by endoscopic band ligation: an in-vivo and ex-vivo pilot study. Endoscopy 35: 823829,2003

9）垂石正樹，岡田優二, 折居史佳ほか : 大腸悡室出血. 老 年消化器病 $15: 93-98,2003$

10) Ramirez FC, Johnson DA, Zierer ST, et al: Successful endoscopic hemostasis of bleeding colonic diverticula with epinephrine injection. Gastrointest Encosc 43: 167170,1996

11）今枝博之, 中溝裕雅，緒方晴彦ほか：大腸悡室出血の内 視鏡治療 (困難例)。消化器内視鏡 $18: 803-805,2006$

12）草野正一, 岡田吉隆, 遠藤 高ほか：小腸の出血性病変 における画像診断の役割. 血管造影による診断と治療を 中心に。胃と腸 $27: 777-785,1992$

13) Adams JT: Therapeutic barium enema for massive diverticular bleeding. Arch Surg 101: 457-460, 1970

14）井上拓也，村野実之，富永裕介ほか：高濃度バリウム注 腸療法が有効であった大腸悡室出血の 1 例. 日本大晹検 查学会雑誌 $24: 31-35,2007$ 


\title{
Diagnosis and Treatment of Bleeding from Colonic Diverticula
}

\author{
Shinsaku Fukuda and Tatsuya Mikami \\ Gastroenterology and Hematology, Hirosaki University Graduate School of Medicine
}

Bleeding is one of the major complications of colonic diverticula. Lower gastrointestinal endoscopy is usually performed at first, when patients have hematochezia. However, if this approach cannot be done or is unsuccessful, we have to rely on other therapeutic techniques, such as interventional radiology or surgical resection.

It is sometimes difficult to find the bleeding diverticulum itself from among multiple diverticula. Even if we cannot find the focus of the bleeding, bleeding from colonic diverticula stops in many cases. However, bleeding may recur when patients take some anticoagulant drugs.

Colonic diverticula have no muscle layer and adventitia, which means that perforation can easily occur. Thus, the use of heat coagulation or pure ethanol injection to get hemostasis is contraindicated in such cases. Endoclips are now thought to be the most useful and safe device for stopping bleeding from colonic diverticula. 